\title{
The long march to Obamacare
}

$\mathrm{T}$ he architects of Obamacare have no time for a victory lap now that President Barack Obama's re-election has secured the future of the law reshaping health care in America. Deadlines are closing in to create new health insurance marketplaces, expand government coverage for the poor and bring millions of the uninsured in from the cold.

The election was the last, best hope for the law's opponents. They needed, most of all, to defeat Obama on Nov. 6. If not that, then to elect a storm surge of Republicans to Congress. They did neither.

The vote produced the status quo: a Democratic president for four more years, a Congress divided once again between Democrats controlling the Senate and Republicans running the House of Representatives. That's a recipe for more of the same, not a conservative revolution, and it's clear the fight has gone out of the opposition.

"Obamacare is the law of the land," John Boehner, leader of the Republican majority in the House, said in a bow to political reality. Those were words Obamacare's supporters surely thought they would never hear from the other side, after feisty protests against the law, repeated attempts in Congress to overturn it and a Supreme Court challenge that nearly did (www.cmaj .ca/lookup/doi/10.1503/cmaj.109-4251).

Although the election was not a direct referendum on the initiative, it might as well have been, so persistent were the vows to repeal it throughout the campaign. It's been a punching bag for Republicans and conservatives everywhere since it was signed into law more than two years ago and began, ever so slowly, to take effect. By far the biggest changes are still ahead.

The Affordable Care Act (www.health care.gov/law/full/index.html), nicknamed Obamacare, guarantees access to health insurance for all Americans at its core. It offers substantial subsidies and consumer protections to help people get

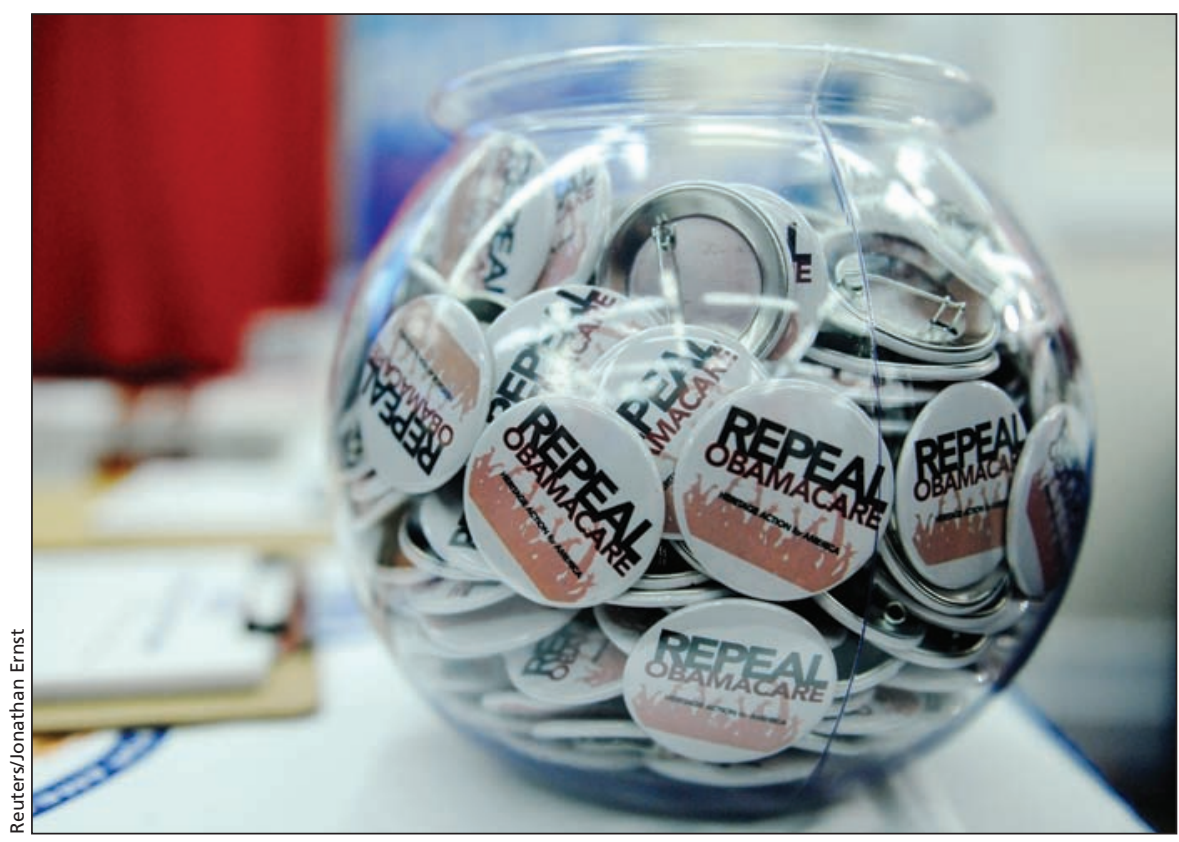

Some political paraphernalia becomes little more than collector's items.

coverage and penalizes those who don't. Altogether, it represents the most far-reaching transformation of health care in the United States since the 1960s, when Medicare and Medicaid were created to provide government insurance to the elderly and the poor respectively.

The aim is to bring some 30 million uninsured Americans into the health care system, building on the private insurance market to achieve the universal coverage that Canada and most other developed countries attained long ago.

Ron Pollack, executive director of the consumer health organization Families USA, says it's going to take a massive public education effort over the next year to extend coverage to tens of millions of uninsured people, many in the dark about what the complex law offers.

But there's no question, he says, that the election means "Obamacare will be implemented, the Medicaid safety net will be strengthened, and Medicare's guaranteed benefits will not be undermined."

States are now up against a deadline to decide if they will establish health insurance exchanges required under the law. If they decide not to do it, alone or in partnership with Washington, the federal government will step in and do it for them.

That puts Republican governors between a rock and a hard place. They don't want to implement a key feature of a law they oppose, but also don't like the feds bigfooting the insurance marketplace on their territory. They'll need to do one or the other before people start enrolling in October 2013.

The online exchanges will offer onestop shopping for competing plans for people who don't get health insurance from their employers and for small businesses that want to offer subsidized coverage to their workers. As many as 25 million people are expected to get coverage this way.

The issue has split Republican-led states. Kansas Governor Sam Brownback sent back a US $\$ 31$ million federal grant last year given to help the state set up its own exchange, waited out the election, then decided not to proceed. "Kansans feel Obamacare is an over- 
reach by Washington and have rejected the state's participation in this federal program," he said. So Washington will create the exchange in Kansas instead.

But in Nevada, with one of the nation's highest rates of the uninsured, fellow Republican Governor Brian Sandoval issued a green light for a new marketplace, saying that "Nevadans are fiercely independent, so we made a decision to build the exchange ourselves, and we are moving forward with that."

Nevada was among more than 20 states that challenged Obamacare in the Supreme Court, but those divisive days seem forgotten on the state's fledgling insurance exchange website, which proclaims: "Health care for all" (http://exchange.nv.gov).

As well, states must decide whether to expand Medicaid, as called for in the law. The US Supreme Court gave states the power to opt out of the expansion but with Washington picking up the tab, there's a strong incentive to stay on board.

So far, elderly Americans have seen improved preventive benefits under Medicare, young people have been granted the right to stay on their parents' health plans until they turn 26 , and insurance companies have been forced to remove lifetime limits on coverage. Otherwise, Obamacare has been largely invisible to the population.

That soon begins to change. Various tax increases start in January, mostly affecting wealthier people, incentives kick in for the creation of health insurance co-ops and subsidies phase in for some prescription drugs.

The big date is Jan. 1, 2014. Then the exchanges will be up and running, while:

- Citizens and legal residents will be required to carry insurance and will be fined if they don't.

- Insurance companies will be forbidden from denying coverage to the sick or charging them more than the healthy.

- Insurers will need to cover a defined set of "essential benefits" at minimum.

- Families whose earnings fall within a wide range of incomes even some earning as much as US\$90 000 for a household of four - will be given subsidies on a sliding scale to make insurance more affordable.

- Companies with more than 50 employees will have to offer insurance to their workers or pay hefty fees to the government.

The law won't be fully in place until 2018, when high-value insurance plans get hit with a tax to help pay for all the rest. By then, Obama will be out of office and the debate will no longer be about his plan, but his legacy. Cal Woodward, Washington DC

CMAJ 2013. DOI:10.1503/cmaj.109-4350 